\title{
Digital Agents: How can Museums Participate in Digital Activism and what are the Tensions therein?
}

\author{
Conni Rosewarne \\ University of Brighton \\ Grand Parade Campus, BN2 OJY, UK \\ connirosewarne@gmail.com
}

\begin{abstract}
Following the inauguration of the Con-Lib coalition government in 2010, there was a wave of politically-oriented exhibitions that appeared in public-funded art museums including the V\&A, Tate, Barbican and the Hayward. The V\&A 2014-5 exhibition 'Disobedient Objects' even made explicit use of activist material, including some from the protests that followed the Con-Lib government's inauguration - such as the protests over university tuition fees and cuts to the NHS - pre-empting a new debate surrounding "the museum as activist" as seen at the Museum's Association 2016 Conference.
\end{abstract}

This presentation discussed the ways that institutions and exhibitions have utilised digital spaces to expand the spaces of political exhibitions, for example, Suzanne Lacy's 'Silver Action' project for BMW Tate Live in 2013 which used social media platform Twitter as its main tool. This talk will explore and question how "the museum as activist" can partake in pre-existing activist discourses organised online, how this terrain can be mapped and documented as part of activist histories (if possible) and what implications this could entail within the limited parameters of the museum as a public-funded institution. 